\title{
PENGARUH EVALUASI ULANGAN HARIAN TERHADAP PENINGKATAN PRESTASI BELAJAR EKONOMI SISWA KELAS X SMA NEGERI 3 PEMATANGSIANTAR
}

\author{
Eka Pratiwi Septania Parapat ${ }^{1)}$, Eve Ida Malau ${ }^{2)}$ \\ ${ }^{1}$ Akuntansi, Sekolah Tinggi Akuntansi dan Manajemen Indonesia \\ email: ekapsparapat@gmail.com \\ ${ }^{2}$ Akuntansi, Sekolah Tinggi Akuntansi dan Manajemen Indonesia \\ email: eveidamalau@gmail.com
}

\begin{abstract}
This study aims to determine the effect of providing daily test evaluation on the improvement of student achievement in economy class X SMA NEGERI 3 Pematangsiantar. The population of this research was all class $X$ as many as 344 people. Samples were taken as many as 86 people, the research was conducted at SMA NEGERI 3 Pematangsiantar.The instrument used to collect data on the provision of daily test evaluations was a questionnaire compiled by the researcher, while the economic learning achievement data were obtained through a list of value sets. The quality of the research instrument was carried out by testing the validity and reliability. By using the normality test, the data for the provision of daily test evaluations were normally distributed. While the linear regression equation is $Y=a+b X$, so the regression of learning achievement $(Y)$ on the provision of daily test evaluation $(X)$ is $Y=50.43$ $+0.38 X$. For analysis accuracy used regression linearity test and using a list of variances (ANOVA) through the $F$ test, it turns out that $Y$ does not need to look for a non-linear model. To determine whether the relationship between variables is close or not, the correlation coefficient test is used as follows: The correlation of providing daily test evaluation with student achievement is 0.359 and the coefficient of determination of $Y$ on $X$ is 0.1288 or $12.88 \%$. Based on hypothesis testing, it is obtained that $F_{\text {count }}$ is greater than $F_{\text {table }}(12.44>3.96)$. Thus $H_{0}$ is rejected and $H_{1}$ is accepted. This means that there is a significant effect of providing daily test evaluations on the improvement of student achievement in class X SMA NEGERI 3 Pematangsiantar
\end{abstract}

Keywords: Daily Test, Learning Evaluation, Learning Achievement

\section{PENDAhULUAN}

Pesatnya arus globalisasi saat ini menyebabkan perubahan pada berbagai aspek kehidupan yang senantiasa menuntut kualitas sumber daya manusia yang tinggi. Dewasa ini pengembangan kualitas sumber daya manusia jadi suatu keharusan, terutama dalam memasuki era globalisasi dan kemajuan Ilmu Pengetahuan dan Teknologi. Untuk dapat memasuki era globalisasi tersebut dan untuk dapat menyerap kemajuan teknologi tiada jalan lain selain melalui pendidikan [1], [2]. Berbagai upaya yang telah dilakukan pemerintah dalam meningkatkan mutu pendidikan, mulai dari tahap pengembangan atau penyempurnaan kurikulum, melengkapi sarana dan prasarana pendidikan, meningkatkan kualitas guru melalui penataran,

pengembangan sistem penilaian hasil belajar dan lain-lain [1]-[3].

Evaluasi ulangan harian pelajaran ekonomi pada tingkat SMA dapat berlangsung pada setiap pertemuan, setiap selesai pokok bahasan, dan bahkan beberapa pokok bahasan yang telah disajikan. Pemberian evaluasi terhadap siswa tersebut diharapkan dapat bermakna positif terhadap perkembangan pendidikan bagi siswa. Sebagai contoh, seorang guru sangat rajin memberikan evaluasi ulangan harian, namun kenyataannya tidak pernah diperiksa dengan baik [3].

Begitu pula tidak ada usaha seorang 
guru untuk mengembalikan hasil pekerjaan siswa tersebut. Padahal hasil evaluasi yang diperoleh siswa merupakan umpan balik sekaligus menjadi acuan terhadap siswa sebagai pembelajaran. Nilainilai yang diperoleh seorang siswa dalam ulangan harian mempunyai arti penting, misalnya dalam penulisan nilai raport, kenaikan kelas, menyelesaikan pendidikan pada jenjang tertentu, meneruskan pendidikan kejenjang yang lebih tinggi [3]-[5]. Maka dalam pengamatan penulis bahwa minat siswa untuk mengulang pelajaran yang telah diberikan oleh guru di rumah sangat rendah, hal ini terlihat dari prestasi yang diperoleh oleh para siswa semakin menurun. Banyaknya waktu yang dipergunakan untuk bermain-main disekolah ataupun ketika berada di rumah, pengaruh perkembangan teknologi yang membuat banyak siswa lebih suka berlama-lama di depan komputer ataupun laptop[6], [7]. Orang tua yang kurang mengontrol perkembangan anaknya di sekolah dan waktu belajar di rumah membuat banyak siswa yang hanya belajar ketika waktu ujian saja [3]. Tidak serius atau kurangnya minat para siswa dalam mengikuti pelajaran yang diberikan oleh guru di dalam kelas dan juga metode pembelajaran yang diberikan oleh guru juga menjadi faktor lambatnya para siswa menerima atau menangkap pelajaran yang diberikan, sehingga hal tersebut juga menjadi faktor menurunnya prestasi belajar siswa [8], [9].

\section{METODE PENELITIAN}

Lokasi penelitian SMA Negeri 3 Pematangsiantar tepatnya pada kelas $\mathrm{X}$ yang beralamat di Jalan Pane No. 38 Pematangsiantar. populasi yang dijadikan sumber data dalam penelitian ini adalah seluruh siswa kelas X SMA Negeri 3 Pematangsiantar yang terdiri dari 10 kelas dengan jumlah siswa keseluruhan sebanyak 344 orang siswa.

Tabel 1. Jumlah Populasi Siswa Kelas X

\begin{tabular}{ccc}
\hline Nomor & Kelas & Jumlah Siswa \\
\hline $\mathbf{1 .}$ & X-1 & 35 orang \\
$\mathbf{2 .}$ & X-2 & 36 orang \\
$\mathbf{3 .}$ & X-3 & 32 orang \\
$\mathbf{4 .}$ & X-4 & 35 orang \\
$\mathbf{5 .}$ & X-5 & 35 orang \\
$\mathbf{6 .}$ & X-6 & 36 orang \\
$\mathbf{7 .}$ & X-7 & 33 orang \\
$\mathbf{8 .}$ & X-8 & 32 orang \\
$\mathbf{9 .}$ & X-9 & 36 orang \\
$\mathbf{1 0 .}$ & X-10 & 34 orang \\
\hline
\end{tabular}

Jumlah 344 Orang

Penentuan besarnya sampel mengacu pada rumus yang dikembangkan Arikunto [10] yaitu: "Untuk sekedar ancar-ancar maka apabila subyeknya kurang dari 100 , lebih baik diambil semua, sehingga penelitiannya merupakan penelitian populasi. Selanjutnya, jika jumlah subyeknya besar maka dapat diambil $10-15 \%$ saja atau 20-25\% atau lebih". Sehingga dalam penelitian ini penulis mengambil sampel sebanyak $25 \%$ dari 344 siswa, yaitu sebanyak 86 siswa, dengan teknik pengambilan secara acak (random sampling).

Dalam penelitian ini peneliti menggunakan metode deskriptif. Adapun yang menjadi alasan peneliti menggunakan metode deskriptif adalah sesuai dengan tujuan penelitian ini yakni ingin menggambarkan situasi dari variabel yang ingin ditetapkan yaitu mengungkapkan apakah ada pengaruh evaluasi belajar dengan prestasi belajar siswa pada mata pelajaran ekonomi [1].

Teknik yang digunakan dalam penelitian ini adalah Teknik dengan menggunakan angket atau kuisioner dan teknik dokumentasi.

\section{Tabel 2. Lay Out Angket Evaluasi Ulangan} Harian

\begin{tabular}{|c|c|c|c|}
\hline No & $\begin{array}{c}\text { Variabel } \\
\text { Penelitian }\end{array}$ & Indikator Penelitian & $\begin{array}{l}\text { No } \\
\text { Item }\end{array}$ \\
\hline 01 & $\begin{array}{c}\text { Evaluasi } \\
\text { ulangan } \\
\text { harian }(\mathrm{X})\end{array}$ & $\begin{array}{ll}- & \text { Motivasi } \\
- & \text { Kompetitif } \\
- & \text { Mandiri }\end{array}$ & $\begin{array}{c}1-6 \\
7-15 \\
16-20\end{array}$ \\
\hline 02 & $\begin{array}{l}\text { Prestasi } \\
\text { belajar (Y) }\end{array}$ & $\begin{array}{l}\text { Nilai raport bidang studi } \\
\text { ekonomi (DKN) }\end{array}$ & \\
\hline
\end{tabular}

Untuk mengetahui validitas dan reabilitas angket dilakukan uji coba instrument, yaitu:

1. Uji Validitas

$r_{\mathrm{xy}}=\frac{\mathrm{n} \sum_{\mathrm{xy}}-\left(\sum \mathrm{X}\right)\left(\sum \mathrm{Y}\right)}{\sqrt{\left\{\left(\mathrm{n} \sum \mathrm{X}^{2}-\left(\sum \mathrm{X}\right)^{2}\right\}\left\{\mathrm{n} \Sigma \mathrm{Y}^{2}-(\Sigma \mathrm{Y})^{2}\right\}\right.}}$

Syarat valid jika $r_{\text {hitung }}>\mathrm{r}_{\text {tabel }}$ pada taraf singnifikan $95 \%$, maka instrument tersebut dianggap valid. Sebaliknya $\mathrm{r}_{\text {hitung }}<\mathrm{r}_{\text {tabel }}$ maka instrument dikatakan tidak valid.

2. Uji Reabilitas

$\mathrm{r}_{\mathrm{ii}}=\left(\frac{k}{k-1}\right)\left(1-\frac{\sum \sigma_{b}^{2}}{\sigma_{t}^{2}}\right)$ 
Angket dianggap reliable $r_{\text {hitung }}>r_{\text {tabel }}$ pada taraf signifikan $95 \%(\alpha=0,05)$ dan jika $r_{\text {hitung }}<r_{\text {tabel }}$ maka dianggap tidak reliable.

Tehnik analisa data berguna untuk pengujian hipotesis, apakah hipotesis diterima atau ditolak. Hipotesis akan diuji kebenarannya dengan menggunakan analisa statistik seperti yang diuraikan di bawah ini.

\section{Uji Normalitas Data}

Sebelum melakukan hipotesis ini, lebih dahulu dilakukan pengujian terhadap normalitas data. Apakah data yang diperoleh berdistribusi normal atau tidak [7]. Sejalan dengan itu peneliti melakukan uji coba terhadap data yang diperoleh yaitu uji normalitas data baik terhadap variabel $\mathrm{X}$ maupun terhadap variable $\mathrm{Y}$ dengan menggunakan kertas peluang normal dengan uji chi kuadrat $\left(\chi_{2}\right)$. untuk menggunakan uji chi kuadrat ini adalah dengan membandingkan chi kuadrat hitung dengan chi kuadrat tabel.

Dimana chi kuadrat hitung diperoleh dari perhitungan dengan rumus:

$\chi^{2}=\sum_{i=1}^{k} \frac{\left(\mathrm{f}^{\prime} \mathrm{o}-\mathrm{f}^{\prime} \mathrm{h}\right)^{2}}{\mathrm{f}^{\prime} \mathrm{h}}$

Sedangkan $\left(\chi^{2}\right)$ table diperoleh dari daftar distribusi chi kuadrat dengan taraf signifikan $\alpha=0,05$ dan $\mathrm{dk}=5-3=2$. Kriteria pengujian: Data berdistribusi normal jika chi kuadrat hitung lebih kecil dari chi kuadrat tabel.

Kriteria pengujian: Data berdistribusi normal jika chi kuadrat hitung lebih kecil dari chi kuadrat tabel dengan taraf pengujian $\alpha=$ 0,05 . Sedangkan chi kuadrat tabel diperoleh dari daftar distribusi chi kuadrat pada taraf 1 $-\alpha$ dan $\mathrm{dk}=\mathrm{k}-3$.

\section{Pengujian Hipotesis}

a. Uji Regresi Linier Sederhana

Diatas telah dijelaskan variabelvariabel yang terdapat dalam penelitian ini, maka untuk selanjutnya perlu pengujian antara variabel yang satu dengan variabel yang lain.

Untuk mengetahui apakah pengaruh minat belajar itu dapat melakukan prediksi/ramalan (X) terhadap prestasi belajar (Y) dilakukan uji linier sederhana dengan rumus: $\hat{\mathbf{Y}}=\mathbf{a}+\mathbf{b} \mathbf{X}$

Dimana harga a dan $b$ dapat diperoleh dari perhitungan dengan metode kuadrat terkecil.

$$
\begin{aligned}
& a=\frac{\left(\sum \mathrm{Y}_{\mathrm{i}}\right)\left(\sum \mathrm{X}_{\mathrm{i}}^{2}\right)-\left(\sum \mathrm{X}_{\mathrm{i}}\right)\left(\sum \mathrm{X}_{\mathrm{i}}\right)\left(\sum \mathrm{X}_{\mathrm{i}} \mathrm{Y}_{\mathrm{i}}\right)}{n \sum X_{i}^{2}-\left(\sum X_{i}\right)^{2}} \\
& b=\frac{\left(\mathrm{n} \sum \mathrm{X}_{\mathrm{i}} \mathrm{Y}_{\mathrm{i}}\right)-\left(\sum \mathrm{X}_{\mathrm{i}} \mathrm{Y}_{\mathrm{i}}\right)}{\mathrm{n} \sum \mathrm{X}_{\mathrm{i}}^{2}-\left(\sum X_{i}\right)^{2}}
\end{aligned}
$$

Keterangan:

$\mathrm{X}=$ Variabel bebas

$\mathrm{Y}=$ Variabel terikat

b. Uji Signifikan Kontribusi Antar Variabel

Untuk menentukan signifikansi antar variable dan untuk menentukan ada tidaknya hubungan antar variable yang mempengaruhi (X) dan variable yang dipengaruhi(Y) dilakukan dengan rumus:

$\sum \mathrm{Y}_{\mathrm{i}}^{2}=\frac{\left(\sum \mathrm{Y}_{\mathrm{i}}\right)^{2}}{n}+\mathrm{JK}(\mathrm{b} / \mathrm{a})+\mathrm{JK}$ Res

Keterangan:

$\sum Y_{\mathrm{i}}^{2}=$ Jumlah kuadrat total

$\mathrm{JK}=$ Jumlah kuadrat

$\mathrm{N}=$ Derajat kebebasan untuk $\mathrm{Y}^{2}$

$\mathrm{b} / \mathrm{a}=$ Koefisien korelasi

Tiap jumlah kuadrat-kuadrat (JK) mempunyai derajat kebebasan masing-masing, yakni n untuk $\sum \mathrm{Y}_{\mathrm{i}}^{2}, 1$ untuk JK (a), 1 untuk JK (b/a) dan (n-2) untuk $\mathrm{JK}_{(\text {res }) \text {. }}$.

\section{Kriteria pengujian:}

$\mathrm{H}_{0}$ ditolak jika $\mathrm{F}_{\text {hitung }}$ lebih besar dari $F$ tabel $\left(F_{h} \geq F_{t}\right)(1 . n-2)$. Dengan taraf signifikansi 1- $\alpha$, dengan $\mathrm{dk}$ pembilang $=1$ dan dk penyebut $(n-2)$ dimana $F_{t}$ dapat diperoleh dari distribusi F. 


\section{c. Uji Signifikansi Koefisien Korelasi Koefisien korelasi merupakan suatu indeks yang bermanfaat untuk menggambarkan taraf pengaruh antara dua variable atau lebih. Koefisien korelasi biasanya berkisar antara $\pm 0,00$ s/d 1,00 (tanda $(+)$ menunjukkan arah pengaruh positif, tanda (-) menunjukkan arah hubungan negatife. Kriteria penafsiran korelasi itu dapat dilihat seperti berikut:}

Tabel 3. Pedoman untuk memberikan interprestasi terhadap koefisien korelasi

\begin{tabular}{ll}
\hline Koefisien $r$ & Pengaruh \\
\hline $\mathbf{0 , 0 0}$ s/d 0,60 & Korelasi Sangat rendah \\
$\mathbf{0 , 2 0}$ s/d 0,40 & Korelasi Rendah \\
$\mathbf{0 , 4 0}$ s/d 0,60 & Korelasi Sedang \\
$\mathbf{0 , 6 0}$ s/d 0,80 & Korelasi Tinggi \\
$\mathbf{0 , 8 0}$ s/d 1,00 & Korelasi Sangat tinggi \\
\hline
\end{tabular}

Koefisien korelasi antara dua variabel disebut korelasi sederhana dinyatakan dengan " $r$ ", sedangkan untuk mengukur hubungan antara tiga variabel atau lebih, disebut korelasi multiple dan dinyatakan dengan $\mathrm{R}$.

Untuk menentukan derajat hubungan antara dua variable yaitu hubungan $X$ dan Y, disebut uji korelasi sederhana dengan menggunakan rumus:

$$
r=\frac{\mathrm{n} \sum \mathrm{X}_{\mathrm{i}} \mathrm{Y}_{\mathrm{i}}\left(\sum \mathrm{X}_{\mathrm{i}}\right)\left(\sum \mathrm{Y}_{\mathrm{i}}\right)}{\sqrt{\left\{\mathrm{n} \sum \mathrm{X}_{1}^{2}-\left(\sum \mathrm{X}_{\mathrm{i}}\right)^{2}\right\}\left\{\mathrm{n} \sum \mathrm{Y}_{1}^{2}-\left(\sum \mathrm{Y}_{1}\right)^{2}\right.}}
$$

\section{Kriteria pengujian:}

Koefisien korelasi dikatakan signifikansi bila koefisien korelasi hitung lebih besar dari harga kritik $\mathrm{r}$ dengan $\alpha=0,05$

d. Uji Koefisien Korelasi dan Koefisien Determinasi

Koefisien korelasi dihitung untuk mengetahui ada tidaknya hubungan antara variabel bebas dengan variabel terikat sedangkan determinasi adalah untuk mengetahui besarnya pengaruh variabel bebas terhadap variabel terikat. Koefisien korelasi simbolnya adalah "r", dan koefisien determinasinya adalah $\mathrm{r}^{2}$. Koefisien korelasi multiple simbolnya adalah $\mathrm{r}^{2}$, dan koefisien determinasinya adalah $\mathrm{R}^{2}$, yang dapat dicari dengan rumus: $r^{2}=100 r^{2} \%$

\section{HASIL DAN PEMBAHASAN 3.1. Uji Instrumen}

Adapun hasil uji instrumen yang dianalisa dari statistik untuk penentuan kualitas instrumen penelitian adalah sebagai berikut:

- Dari hasil perhitungan uji validitas angket (Lampiran V) pemberian evaluasi ulangan harian untuk no item 1 diperoleh koefisien korelasi hitung sebesar 0,286 sedangkan koefisien korelasi dari tabel harga kritk product moment $\alpha=0,05$ dan $\mathrm{n}=86$ adalah 0,213. sedangkan koefisien $\mathrm{r}_{\text {hitung }}$ lebih besar dari koefisien $r_{\text {tabel. }}$ Yakni $r_{\text {hitung }}=0,286>$ $\mathrm{r}_{\text {tabel }}=0,213$ ini berarti angket pemberian Evaluasi ulangan harian untuk no item 1 adalah valid.

- Dari hasil perhitungan (Lampiran VI) uji reliabilitas angket pemberian evaluasi ulangan harian diperoleh koefisien korelasi hitung sebesar 0,588 sedangkan koefisien korelasi dari tabel harga kritik produk moment $\alpha=0,05$ dan $n=86$ adalah 0,213 . Sedangkan koefisien $r$ hitung lebih besar dari koefisien korelasi $r$ tabel $(0,588>0,213)$ ini berarti angket pemberian evaluasi ulangan harian adalah reliabel.

\subsection{Normalitas Data Kriteria pengujian:}

Data berdistribusi normal jika chi kuadrat hitung lebih kecil atau sama dari chi kuadrat tabel.

- Uji normalitas pemberian evaluasi ulangan harian (X) 
Untuk menyusun daftar distribusi frekuensi dari pemberian evaluasi ulangan harian dilakukan prosedur sebagai berikut:

Rentang $=$ skor terbesar - skor terkecil

$$
=79-52=27
$$

Banyak kelas $=1+3,3 \log \mathrm{n}$

$$
=1+3,3 \log 86
$$$$
=1+6,38
$$$$
=7,38
$$

(yang digunakan 7)

$$
\begin{aligned}
\text { Panjang kelas } & =\frac{\text { Rentang }}{\text { Banyak kelas }} \\
& =\frac{27}{7,38} \\
& =3,65 \\
& \text { (yang digunakan } 4 \text { ) }
\end{aligned}
$$

\begin{tabular}{|c|c|c|}
\hline Kelas interval & Tabulasi & $\mathbf{F}$ \\
\hline $52-55$ & HIII IIII & 9 \\
\hline $56-59$ & HIH HН IIII & 14 \\
\hline $60-63$ & HIH HIH HII IIII & 19 \\
\hline $64-67$ & Ш Щ世 Ш世 Ш世 & 20 \\
\hline $68-71$ & 世世 Ш世 IIII & 14 \\
\hline $72-75$ & 世H IIII & 9 \\
\hline $76-79$ & I & 1 \\
\hline \multicolumn{2}{|c|}{ JUMLAH } & 86 \\
\hline
\end{tabular}

Setelah diketahui panjang kelas dan banyak kelas maka dapat disusun daftar penolong Pemberian Evaluasi Ulangan Harian (X)

Tabel 4. Daftar Penolong Frekuensi Pemberian Evaluasi Ulangan Harian

Sumber : Data Primer

Setelah diperoleh tabulasi data jumlah

\begin{tabular}{|c|c|c|c|c|c|}
\hline $\begin{array}{c}\text { Kelas } \\
\text { interval }\end{array}$ & $\mathbf{X}$ & $\mathbf{F}$ & d & Fd & $(\mathbf{f d})^{2}$ \\
\hline $52-55$ & 53,5 & 9 & -3 & -27 & 81 \\
\hline $56-59$ & 57,5 & 14 & -2 & -28 & 56 \\
\hline $60-63$ & 61,5 & 19 & -1 & -19 & 19 \\
\hline $64-67$ & 65,5 & 20 & 0 & 0 & 0 \\
\hline $68-71$ & 69,5 & 14 & 1 & 14 & 14 \\
\hline $72-75$ & 73,5 & 9 & 2 & 18 & 36 \\
\hline $76-79$ & 77,5 & 1 & 3 & 3 & 9 \\
\hline
\end{tabular}
frekuensi setiap kelas interval maka dapat dibuat tabel distribusi frekuensi unttuk mencari rata-rata dan simpangan baku.

Tabel 5. Daftar Distribusi Frekuensi Pemberian Evaluasi Ulangan Harian

\begin{tabular}{rrrr}
\hline 86 & -39 & 215 \\
\hline
\end{tabular}

Sumber : Data Primer

Berdasarkan hasil perhitungan pada tabel, maka dapat dihitung rata-rata $(\bar{x})$ dan simpangan baku (s) sebagai berikut:

$$
\begin{aligned}
\bar{x} & =\bar{x}_{0}+i\left[\frac{\sum f d}{n}\right] & s & =i \sqrt{\frac{\sum f d^{2}}{n}-\left(\frac{\sum f d}{n}\right)^{2}} \\
& =65,5+4\left[\frac{-39}{86}\right] & & =4 \sqrt{\frac{215}{86}-\left(\frac{-39}{86}\right)^{2}} \\
& =65,5-1,8 & & =4(1,516) \\
& =63,7 & & =6,1
\end{aligned}
$$

Hasil perhitungan di atas diperlukan untuk menyusun daftar tabel perhitungan frekuensi yang diharapkan dan frekuensi pengamatan Perhitungan Chi Kuadrad Pemberian Evaluasi Ulangan Harian yang di dapat Dari hasil perhitungan diperoleh $\chi_{\text {hitung }}^{2}=3,38$, sedangkan $\chi_{\text {tabel }}^{2}$ pada taraf signifikansi 0,05 dan $\mathrm{dk}=7-3=4$ yaitu 9,49 . Dengan demikian maka $\chi_{\text {hitung }}^{2}<\chi_{\text {tabel }}^{2}(3,38<9,49)$, sehingga data Pemberian evaluasi ulangan harian adalah berdistribusi normal.

\subsection{Persamaan regresi linier}

Dari hasil perhitungan a dan b diatas, maka persamaan regresi linier sederhana mengenai pemberian evaluasi ulangan harian dengan prestasi belajar di SMA Negeri 3 Pematangsiantar dapat dituliskan sebagai berikut: $\quad Y=50,43+0,38 X$

\subsection{Uji signifikansi kontribusi antar variabel}

Tabel 6. Daftar analisa varians regresi linier sederhana

\begin{tabular}{lcccc}
\hline $\begin{array}{c}\text { Sumber } \\
\text { variasi }\end{array}$ & Dk & JK & KT & F \\
\hline Regresi & 1 & 479857,86 & 479857,86 & \\
a & & & & \\
Regresi & 1 & 470,92 & 470,92 & 12,4425 \\
b|a & 84 & 3179,22 & 37,8478 & \\
Residu & 84 & & \\
Jumlah & 86 & 483508 & & \\
\hline
\end{tabular}

Sumber : Data diolah 
Dari daftar di atas, maka $\mathrm{F}_{\text {hitung }}$ ditentukan dengan rumus:

$$
F=\frac{S_{\text {reg }}^{2}}{S_{\text {res }}^{2}}=\frac{470,92}{37,8478}=12,4425
$$

Dari daftar distribusi $F$ dengan $\alpha=0,05 \mathrm{dk}$ pembilang 1 dan $\mathrm{dk}$ penyebut $=\mathrm{n}-2=86-2=$ 84, maka $\mathrm{F}_{(0,95)(1,84)}=3,96$ ternyata $\mathrm{F}_{\text {hitung }}$ lebih besar dari $F_{\text {tabel }}(12,44>3,96)$. Dengan demikian $\mathrm{H}_{0}$ ditolak dan $\mathrm{H}_{1}$ diterima. Ini berarti bahwa ada pengaruh yang positif dan signifikan dari pemberian evaluasi ulangan harian terhadap peningkatan prestasi belajar siswa kelas X SMA NEGERI 3 Pematangsiantar

\subsection{Uji lineritas regresi}

Pengujian linieritas dilakukan dengan $F_{\text {hitung }}$ dengan $\mathrm{F}_{\text {tabel. }} \mathrm{F}_{\text {hitung }}$ dicari dengan rumus:

$$
F=\frac{S^{2} T C}{S^{2} e}
$$

\section{Dengan kriteria pengujian:}

Jika harga $F_{\text {hitung }}$ lebih kecil dari $F_{\text {tabel }}$ pada taraf signifikansi $1-\alpha$ dengan $\mathrm{dk}$ pembilang $\mathrm{k}-2$ dan $\mathrm{dk}$ penyebut $\mathrm{n}-\mathrm{k}$ maka hipotesis model linier $\mathrm{Y}$ atas $\mathrm{X}$ dapat diterima dan sebaliknya.

Uji linieritas Pemberian evaluasi ulangan harian (X) atas Prestasi belajar siswa (Y) dapat dihitung sebagai berikut

$$
\begin{aligned}
& \mathrm{JK}(\mathrm{E})=2257,057 \\
& \begin{aligned}
J K(T C) & =J K_{\text {res }}-J K(E) \\
& =3179,22-2257,057 \\
& =922,163
\end{aligned}
\end{aligned}
$$

Tabel 7. Tabel ANAVA Uji Linieritas

\begin{tabular}{lcccc}
\hline $\begin{array}{c}\text { Sumber } \\
\text { variasi }\end{array}$ & Dk & JK & KT & F \\
\hline Jumlah & 86 & 483508 & & \\
regresi a & 1 & 479857,86 & 479857,86 & \\
regresi b|a & 1 & 470,92 & 470,92 & 12,4425 \\
Residu & 84 & 3179,22 & 37,8478 & \\
Tuna & 22 & 922,163 & 41,9165 & 1,1514 \\
cocok & & & & \\
Kekeliruan & 62 & 2257,057 & 36,4041 & \\
\hline
\end{tabular}

Sumber : Data diolah
Jadi $\mathrm{F}$ hitung dari:

$$
F=\frac{S^{2} T C}{S^{2} e}=\frac{41,9165}{36,4041}=1,1514
$$

Dari daftar distribusi $\mathrm{F}$ dengan $\alpha=0,05 \mathrm{dk}$ pembilang 22 dan $\mathrm{dk}$ penyebut $=62$ diperoleh nilai $F_{\text {tabel }} 1,73$. Sedangkan Fhitung diperoleh 1,151 maka $F_{\text {hitung }}<$ dari $\mathrm{F}_{\text {tabel }}$ yakni $(1,151<1,73)$, maka ditafsirkan bahwa model regresi linier diterima.

\subsection{Korelasi dalam regresi linier}

Dari hasil perhitungan koefisien korelasi hitung diperoleh $\mathrm{r}_{\text {hitung }}=0,359$ sedangkan koefisien korelasi dari harga kritik $\mathrm{r}$ product moment untuk $\alpha=0,05$ dan $\mathrm{n}=86$ diperoleh 0,213 , sehingga koefisien korelasi $\mathrm{r}_{\text {hitung }}$ lebih besar dari koefisien korelasi $r_{\text {tabel }}(0,359>0,213)$, maka dapat disimpulkan ada hubungan antara pemberian evaluasi ulangan harian dengan peningkatan prestasi belajar siswa (korelasi yang signifikan).

\subsection{Koefisien Korelasi Determinasi}

Kontribusi antara pemberian evaluasi ulangan harian (X) dengan peningkatan prestasi belajar siswa $(\mathrm{Y})$ sehingga diperoleh $r=0,359$ maka $r^{2}=$ $(0,359)^{2}=0,1288$ dengan demikian pengaruh pemberian evaluasi ulangan harian terhadap prestasi siswa dinyatakan dalam bentuk presentase sebagai berikut:

$$
100 \mathrm{r}^{2} \%=100 \times 0,1288 \%=12,88 \%
$$

\section{KESIMPULAN}

Penelitian yang dilakukan penulis "Pengaruh pemberian evaluasi ulangan harian terhadap peningkatan prestasi belajar ekonomi siswa kelas $\mathrm{X}$ SMA NEGERI 3 Pematangsiantar" dengan jumlah sampel 86 orang. Alat pengumpulan data adalah angket dan daftar kumpulan nilai. Dari hasil penelitian menunjukkan bahwa pemberian evaluasi ulangan harian mempengaruhi peningkatan prestasi belajar ekonomi siswa. 


\section{REFERENSI}

[1] M. Sdam, "Pengaruh Pemberian Evaluasi Ulangan Harian Terhadap Penigkatan Motivasi Belajar Bahasa Indonesia Pada Siswa Tingkat Smp Kabupaten Maros.Pdf." Jurnal Pendidikan dan Kebudayaan, pp. 452468, 2007.

[2] L. A. Bahalwan, "Sistem Ulangan Harian Dengan Penentuan Tingkat Kesulitan Soal Menggunakan Algoritma Naive Bayes Classifier," Pros. Semin. Nas. Ilmu Komput. dan Teknol. Inf., vol. 4, no. 2, pp. 50-54, 2019.

[3] I. E. Mulyaningsih, "Pengaruh Interaksi Sosial Keluarga, Motivasi Belajar, Dan Kemandirian Belajar Terhadap Prestasi Belajar," $J$. Pendidik. dan Kebud., vol. 20, no. 4, pp. 441451, 2014.

[4] M. D. Nana Harlina Haruna, "Pengaruh Model Pembelajaran Kooperatif Tipe Make a Match Terhadap Hasil Belajar," J. Publ. Pendidik., vol. 10, no. 3, pp. 223-231, 2020.

[5] L. A. Ghullam Hamdu, "Pengaruh Motivasi Belajar Siswa Terhadap Pestasi Belajar IPA Di Sekolah Dasar," J. Penelit. Pendidik., vol. 12, no. 1, pp. 81-86, 2011.

[6] A. A. Kocimaheni, S. Pd, and M. Pd, "Analisis Program Remedial dalam Mencapai Kriteria Ketuntasan Minimal Ulangan Harian Bahasa Jepang," HIKARI J. Ilm. Mhs., vol. 4, no. 2, pp. 205-214, 2020.

[7] U. Aiman, "Evaluasi Pelaksanaan Penilaian Autentik Kurikulum 2013," J. Pendidik. Madrasah, vol. 1, no. 1, pp. 115-122, 2016.

[8] P. N. Aini and A. Taman, "Pengaruh Kemandirian Belajar dan Lingkungan Belajar Siswa Terhadap Prestasi Belajar Akuntansi," J. Pendidik. Akunt. Indones., vol. X, no. 1, pp. 48-65, 2012.

[9] Dessy Mulyani, "Hubungan Kesiapan Belajar Siswa Dengan Prestasi Belajar," J. Ilm. Konseling, vol. 2, no. 1, pp. 27-31, 2013.

[10] Arikunto, S., 2006. Metodelogi penelitian. Yogyakarta: Bina Aksara 